\title{
Becoming Editor: Or, Pinocchio finally notices the Strings
}

\author{
Martin Parker
}

\author{
*School of Management, University of Leicester. Leicester.m.parker@le.ac.uk
}

\begin{abstract}
This paper uses my experience as an academic journal editor in order to reflect upon the social arrangement that brings academics, universities, states and knowledge capitalist organizations together to produce the contemporary academic journal and access paywalls. After some consideration of the history of publishing, I analyse the market for articles like this one, and consider the consequences of the ranking and monetization of journals, papers and citations by different agents. As I do this, I insert various biographical reflections on the relationship between 'editing' and being 'edited'. The overall aim of the paper is to suggest that this set-up actually has some very negative consequences for taxpayers, academics and students. It encourages the overproduction of academic output because it turns it into a commodity which is traded, whilst simultaneously tending to discourage forms of knowledge production that fail to fit into the boxes which have already been established for them, whether in terms of content or style. I conclude with some thoughts on open access journals, and their limits.
\end{abstract}

Keywords: editing, journals, publishing, universities, rankings, open access

Acknowledgement: Thanks to Mark Tadajewski for the quote and David Harvie, Craig Pritchard and Robyn Thomas for their comments.

\section{Introduction}

"Ownership of the Journal

The Publisher is the sole and exclusive owner of the legal goodwill in the Journal, the title of the Journal and all rights to the Journal, including copyright and renewals and extensions of copyright, the exclusive right to publish, distribute, license and sell the Journal in any forms, media and language throughout the world. The Editors acknowledge that they have no right, title, or interest therein (SAGE Publications Ltd, Memorandum of Agreement, 2011)".

In this paper, I will be using my experience as an academic journal editor in the area of critical management studies in order to reflect upon the social arrangement which brings together academics, universities, states and knowledge capitalist organizations in order to generate what might look like positive outcomes all round. Along the way, I will analyse the market for selling articles and consider the consequences of the ranking and monetization of journals, papers and citations by different agents. The aim of this paper is to suggest that this set-up actually has some very negative consequences for taxpayers, academics and students. In brief, it encourages the overproduction of academic output because it turns it into a commodity which is traded, whilst simultaneously tending (in some quite complex ways) to discourage forms of knowledge production that fail to fit into the boxes which have already been established for them, whether in terms of content or style. Since I was a journal editor for five years (of the SAGE owned Organization from 2008-2012) I will be relying on those experiences as part of my data'.

I don't think that this paper could be described as an "auto-ethnography", despite the fact that it is punctuated by a personalised account. One of the difficulties with such a genre is the way that it textually overplays agency and subjectivity, and tends to make the structural,

\footnotetext{
${ }^{1}$ An important caveat. From 2010 onwards, Organization operated with two Editors-in-Chief. This article reflects the opinions of one ex-editor, and not the two current editors. As for other people's opinions of what I did, well, you'll have to ask them.
} 
systemic or institutional fade into the background. Reflexive accounts explore certain elements of personal experience (Parker 2004, Sparkes 2007), but might not necessarily tell us a great deal about the general features of the social world. This becomes clear if we think about the role of the journal editor. This person appears to be an example of a decision maker with superior powers of agency, a person with the power to shape their world and that of others. They might be modest, critical, and show us what lies on the other side of the curtain on occasion, but their account will still tend to show that they were the one who made the decisions. I'm not sure that this was my experience, and that is why I have tried to relate my particular impressions to general tendencies, hopefully to show how my "decisions" were often not "mine", or how I was edited by the structures of editing. This is relevant to the question of open access, because commercial publishers were only one of the institutions pulling the strings. Take them out of the system, and there are still plenty of reasons to be sceptical about academic journals.

\section{Publishing}

There is no intrinsic reason why those who teach in universities should have to publish what they think, or what they say in the classroom. Indeed we can assume that the vast majority, for most of the history of universities, haven't felt under such an obligation. To teach well, eat well, perhaps to become chair of the department, would be enough. For some, a little writing might have been possible - perhaps a well-considered book published by a decent university press, or an article in an appropriate scholarly journal. But no rush, because there was little to be gained by haste. If we compare this sedate state of affairs with the frenzy of communication that constitutes the university nowadays, the problem for this article begins to emerge.

In the research universities of the global north, PhD students are now told that they must publish in order to get jobs. Professors are assumed to have stacked up a CV that demonstrates their eminence through publishing. Institutional and national assessment exercises make published output the key criteria for success, and global academic publishers loudly hawk their latest product. It all adds up to a context within which publishing is the key performance indicator, for self and others. If you want to get ahead, then you should measure yourself by output, and measure others in the same way. This is not to say that teaching is irrelevant, because that is measured too, and academic administration and management clearly matter in terms of the sorts of rewards and careers that universities can offer. Nonetheless, I would argue that the pre-eminent criterion is what you have published, in the narrowest sense of that term. It matters less why something was written, or how it was written, or whether anyone reads it, than the simple matter of it being published (Harvie 2000, Post 2012, Parker 2014).

Ever since the invention of the printing press, commercial publishing has been a rather high-risk affair. As with many other cultural products, books, newspapers and periodicals cost money to produce and distribute, and publishers would often lose money. Academic publishing might have been able to define its audience more clearly, but it also had a smaller audience and hence less likelihood of substantial sales. Following the expansion of higher education in the global north from the 1950s onwards, the standard hedge against risk was the textbook - a book that was intended to be sold to students and hence had the possibility of much higher levels of sales. This species of book was distinguished from the monograph, edited collection, or further reading on the basis of its potential profitability. This was a particularly effective strategy in English speaking markets, in high growth areas such as law, psychology and business, and in cross-disciplinary areas such as research methods.

It became the standard way for commercial publishers to try and make money from the academic market. Until, that is, the possibilities of journals became clear from the early 1990s onwards. Academic journals rapidly became growing and profitable areas of academic publishing (Pirie 2009, Beverungen et al. 2012, Harvie et al. 2012). For the academics and their institutions, they provide regular outlets for publications and can be expanded to meet new demands, both in terms of the number of issues a journal publishes, and the development of new specialist journals. For the publishers, they externalise most of the labour costs 
and editorial functions to universities, have fairly predictable organizational demands on publishers themselves, and are structurally designed to encourage repeat subscriptions and hence a stable annual cash flow.

One of the key actors in this set-up is the journal editor, usually an academic with a full time job. Becoming an editor means stepping into a position which is highly structured, and in which the landscape of word lengths, style, accept, revise and reject decisions are already shaped by the complex demands of various interested parties. Their labour and legitimacy are the hinge which connects the profitability of global publishing to the careers of academics, and which provides various ranking agents with material to further their interests. This is not the way that they are usually represented of course, because the standard account would suggest that editors are agents who have power, not the puppets of structure. Indeed, many accounts of journal editing suggest that editors are special people who have more wisdom and experience than others (Hodges 1998, Hojat 2003, Williams 2010). They are minor academic celebrities in their fields, and are courted on the assumption that they know things and can do things.

When I became editor of Organization in 2008, I did so reluctantly. It was a journal I knew well, had been on the board of for a long while, and that I had published in often, but I also had some idea about the sheer amount of work that was involved in producing six issues of an academic journal per year. For most authors, journals just happen. They are the subject of endless gossip, of moaning about stupid reviewers and inconsistent editors, but these are usually like the conversations that the English have about the weather - it's a terrible business, but there's nothing we can do about it. I just didn't want to volunteer for this amount of work. I would rather be writing my own stuff, and had some idea about the amount of time I would have to spend reading things I didn't want to read, writing emails I didn't want to write, and going to conferences that didn't interest me. But I did care about this journal, and the sorts of thinking it represented, and I did feel some sort of responsibility when asked. Eventually, my arm was twisted, and I agreed.

\section{How We Got to Where We Are}

The earliest journals were established to disseminate ideas to a very limited public, and though this may have included those working in universities, they were by no means limited to them. In France, on Monday $5^{\text {th }}$ January 1665 a twelve page pamphlet called the Journal des sçavans, was founded by Denis de Sallo. It is generally regarded as the first scientific journal, but also carried many items of general information such as legal reports, obituaries, and histories. The journal ceased publication in 1792, and then briefly reappeared in 1797 under the title Journal des savants. It did not re-commence regular publication until 1816, as a primarily literary journal and still exists today. In the English-speaking world, the first publication to be understood as a journal was the Philosophical Transactions of the Royal Society of London, which began publishing on the 6th March 1665.

In the marketplace of ideas that broadly follows the enlightenment, the key issue that any publication faces is the problem of trust (Shapin 1994). Anyone could now claim anything, and broadcast it widely, but what credibility should readers give to what they read? This went for accounts of news, politics, history and scientific experiments. Who do we believe? The journal has a particular response to this issue, which is to suggest that it is itself an institution that can be trusted. The burden of trust is moved from the individual author, who may have all sorts of reasons for convincing us of a particular account of the movement of blood around the body, the heating which results from the compression of gases, or a theory of political economy. What the journal does is to establish, usually via connections to forms of social influence (whether class, status or power) that it is an honest broker. Editors, editorial boards, connections to societies or universities, and sponsors can all be used to establish the idea of a collective of individuals whose good reputation is attached to that which it publishes. This reflects the idea of the growth of "science" as a form of truth seeking undertaken by gentlemen, and which is independent from the influences of church, state and commerce. The journal, in this sense, is not a newspaper, a chap book, a tract, magazine or pamphlet. It 
is a regularly produced account of the discoveries of a particular group of people, and hence allows for the possibility of a progressive version of knowing. A "paper" published in 1665 can be referred to in 1666, and its findings elaborated or contradicted based on new evidence.

The growth of scientific journals is hence one part of the institutional apparatus of research, and of the university as a research institution. As a collective and trusted record of practices it provides for the possibility of dissemination, disagreement and embeds the very idea of intellectual progress in its chronological structure. It was a successful innovation, and one which spread across the entire range of subjects taught in the expanding universities of the nineteenth and twentieth century. At the same time, the expansion of journals reflected the divisions of knowledge and departments within the university itself. Natural philosophy becomes chemistry, physics and biology, which in turn become divided into smaller and smaller subdivisions with their own journals to record their specific discoveries. As part of the legitimation process of new disciplines, they also need to establish their own journals. As before, this means arranging a network of people and institutions (such as an editorial board) in order to make a claim about the robustness and credibility of the research area.

Which brings us to management studies, as a specific case of a general process. Whilst the first business schools date from the $19^{\text {th }}$ century, the first journals arrive a century later. Harvard Business Review dates from 1922, but is an edited glossy magazine that employs ghostwriters to help academics polish their prose, so doesn't really count. Human Relations was founded in 1947, Administrative Science Quarterly in 1956 and the Academy of Management Journal in 1958. They each have different institutional backgrounds, but collectively represent the beginnings of an attempt to make questions of managing and organizing into distinct topics which can be written about by a distinct group of knowledge producers. So the founding of a journal is a claim about the boxes into which knowledge should be placed, but also about the institutional location of the people who should legitimately be regarded as associated with this knowledge. In doing this, there is a symmetrical claim about the sort of people who are not fully engaged with these particular forms of knowledge production, which in the case of management then divides it from sociology, economics, history, psychology and so on.

So at this time, in the mid twentieth century, the journal is several things. It is a legitimating claim about a certain form of knowledge which relies on constructing the idea of a trust, an outlet for a broadly progressive account of academic progress, and a disciplinary reflection of the departments of the university and research specialisms. What it is not, is a commercial project intended to make money, or an object which is statistically scrutinised in order to sell that knowledge for money.

There is undoubtedly an element of self-importance in taking on a role like this. "Editor-inChief" made me sound as if I mattered, as if I were a player, as if my opinions were ones that people cared about. I altered my email signature, and felt smug. For the first time in my life, a publisher bought me lunch in a restaurant in a fashionable area of London, and I had salmon with lemon foam and pretended to be interesting and witty. At that lunch, I was joking about how we might increase the circulation of the journal, and suggested including TV listings or centre spreads of famous critical management people naked. It was at that point that the SAGE employee reminded me, with a cool smile and cooler eyes, that it was the publisher who appointed the editor. For the first time, I had a hint that I was an employee, and not anything very much-in-chief, and I watched my lemon foam collapse.

\section{Horizontal Integration}

"Non-Competition and Confidentiality

5.1 The Editors shall keep confidential any business or commercial information regarding the Publisher's plans, policies, subscribers, trade matters or secrets or financial affairs not generally known to the public which the Editors have access or which comes to the Editors attention as a result of the contractual relationship hereunder. This provision shall survive the termination of this agreement" (SAGE Publications Ltd, Memorandum of Agreement, 2011). 
From the 1990s onwards, academic publishing begins to change. As with many industries, including the cultural industries, the tendency has been towards a series of consolidations which have replaced many small organizations with a fewer number of large ones. Most of these new organizations view themselves as global knowledge providers and are driven by shareholder value. In analytic terms, they are best understood as global capitalist corporations which use a variety of strategies to maximise their profitability. As Informa's website claims: "We deliver high quality knowledge and services through multiple channels in markets and regions all over the world"2. According to Harvie et al (2012), Informa had a "publishing turnover" of $£ 294$ million in its latest financial statements, and it was by no means the largest company. It owns Datamonitor, Lloyds List, Taylor \& Francis and various other organizations. Taylor \& Francis in turn owns Routledge, Spon Press, Carfax, Cavendish Publishing, Martin Dunitz, Europa Publications, Gordon \& Breach, Curzon Press, Fitzroy Dearborn, Garland Science, Bios Scientific Publishers Limited, Frank Cass, CRC Press and others. These are not simple publishers, but organisations which, as another publishing giant Cengage expresses it, are "Shaping the Future of Global Learning".

Reed Elsevier, Springer, Wiley, Pearson, Informa and Cengage are companies that have primarily engaged in a strategy of horizontal integration where academic publishing is concerned. That is to say that they have acquired a series of brands which mostly do similar things, and their business model is based on multiplying the number and volume of the brands that they own. SAGE Publications is another example of this strategy. In 2011, they claimed to be publishing 630 journals in the social sciences, of which 67 were in management $^{3}$. Some of these journals they publish on behalf of a professional association of some kind - such as the British Sociological Association or the European Group for Organization Studies - others they own - such as Organization. The social sciences have been a profitable area in this regard, because they have gradually (though not universally) moved to publication practices which are more like those of science. Whilst the arts and humanities have also been moving in this direction too, book based dissemination still has more credibility and journals are not the gold standard in the way that they are now in management.

Organization commenced publishing in 1994, at the beginning of the long journal boom. It is now a medium sized journal specializing in "critical" work, in the top quarter of the rankings, with an international editorial board and a steady flow of papers. By the time I finished my term at the end of 2012, the two Editors-in-Chief were being paid just over $£ 40 \mathrm{k}$ in royalties per year. This was used to employ a Managing Editor for a few days a week to cover the administrative duties, cover one day a week buyouts for the Editors-in-Chief from their respective institutions, as well as the expenses of organizing editorial meetings at conferences for unpaid Associate Editors and members of the editorial board, sponsoring events and so

\footnotetext{
${ }^{2}$ Unless otherwise specified, the data comes from company websites accessed in March 2011.

${ }^{3}$ The list of Management journals alone gives an idea of the scale of the operation as well as the increasingly intricate divisions of knowledge that are being exploited. Accounting History, Action Research, Advances in Developing Human Resources, Asia Pacific Journal of Human Resources, Asian Journal of Management Cases, Australian Journal of Management, Business \& Society, Business Communication Quarterly, Business Information Review, Compensation \& Benefits Review, Economic and Industrial Democracy, Economic Development Quarterly, Educational Management Administration \& Leadership, European Journal of Industrial Relations, Family Business Review, Global Business Review, Group \& Organization Management, Human Relations, Human Resource Development Review, International Journal of Cross Cultural Management, International Small Business Journal, The Journal of Applied Behavioral Science, Journal of Business Communication, Journal of Entrepreneurship, The Journal of Environment \& Development, Journal of Health Management, Journal of Hospitality \& Tourism Research, Journal of Human Values, Journal of Industrial Relations, Journal of Leadership \& Organizational Studies, Journal of Macromarketing, Journal of Management, Journal of Management Education, Journal of Management Inquiry, Journal of Marketing Education, Journal of Service Research, Journal of Sports Economics, Journal of Travel Research, Journal of Vacation Marketing, Labor Studies Journal, Leadership, Management \& Organizational History, Management Communication Quarterly, Management in Education, Management Learning, Marketing Theory, National Institute Economic Review, Nonprofit and Voluntary Sector Quarterly, Organization, Organization \& Environment, Organization Studies, Organizational Research Methods, Public Finance Review, Public Works Management \& Policy, Review of Market Integration, Simulation \& Gaming, Small Group Research, Strategic Organization, Transfer, Work and Occupations, Work, Employment and Society.
} 
on. This was based on a $12.5 \%$ royalty rate on subscriptions, licenses, permissions, bundles, pay per view and so on - so an income of around $£ 320$ thousand per year from this one journal. If we further assume that this is a fairly average figure for SAGE journal income (based on its mid ranking position) then the income from Management journals alone would be just shy of $£ 24$ million 4 .

From 2010-12, the two editors had personal Memoranda of Agreement with SAGE which stipulated various requirements that the company has of the editors. It has the right to hire and fire editors, and early versions of the contract also stipulated that the editors could not do any work for any competitor company without requesting permission from SAGE first. The contract is framed in terms of the "responsibilities" of the editors for providing timely, accurate and appropriate copy, copyright forms, permissions, maintaining the editorial board and so on. They also warrant that everything they submit will not result in any legal cases for libel or copyright, and indemnify the publishers against any costs. The contract is also clear that apart from these "responsibilities", everything else is decided by SAGE. The "Aims and Scope" of the journal cannot be changed without prior agreement with the publisher, and all final decisions on publication of particular items rest with SAGE. The point is that this is an employment relationship, though admittedly a rather unusual one. Both editors also have employment contracts with their respective universities, but one day a week they work for a publisher. The universities are happy with this arrangement because of the esteem which it brings, even though the agreed buyouts cover much less than $20 \%$ of their salaries.

The actual costs of producing a journal are much higher than this but are also met by universities. For Organization, there are around 20 Associate Editors (AEs) who give some of their time to working for SAGE for free, and hundreds of reviewers who do the same. If we then add the labour of actually producing the content for the journals then it is clear that SAGE are getting something of a bargain. Labour is being donated to the journal, mostly time paid for by other employers, and even without access to the accounts we can assume that this is rather an elegant business model. One that can't really fail but to be profitable.

When you are perceived to be someone who has power, people treat you differently. The most obvious ways in which this happened to me were at academic conferences, events which I have been attending for years, but which suddenly became different. For a start, I was now arranging editorial boards and dinners at conferences, but also being asked to sit on "meet the editors" panels, turn up at receptions, go for lunch with publishers or editors and so on. This meant that I attended papers less, and went to conferences to go to the meetings which shadow conferences, and which seem to signify that you are an insider who occupies the spaces of a different event, not merely someone who goes into seminar rooms to listen to other people talk. Only at some conferences though, because when I attended the huge Academy of Management conferences, my meetings were not important ones, and most of the North American academics that I met hadn't heard of Organization at all. They were politely interested nonetheless, and smiled at me as their eyes scanned the rest of the room, but I was unlikely to hear from them again because they would get no credit for donating labour to somewhere that they had never heard of.

\section{Vertical Integration and Ranking Entrepreneurs}

The production and sale of all these journals produces a similar problem that the earliest journals had. In a marketplace for knowledge, who are we to trust? In the absence of social relations given a density by a shared class and location (Shapin 1994), the solution is similar to that developed in a range of other areas in market regimes, which is to develop some sort of ranking system which can turn a series of providers into what looks like a meritocracy with rules for going up and down. Customers can then putatively know which school to choose, which hospital is the best one, or which journal has the best reputation. Supposedly providing a solution for information asymmetry, customers can refer to organisations which do the

\footnotetext{
${ }^{4}$ I'm not making any assumptions about profit here, because I don't know how much it costs to produce the journal, and because SAGE are an US family owned company who don't need to publish accounts. See McCune (2010) for a story about their growth. For a different story see the Editorial in Monthly Review (2012).
} 
ranking for us, such as government agencies; trade, professional or consumer associations; and commercial companies (such as rating agencies) who will supply these lists at a profit.

The ranking of journals hence becomes a potential service to sell, and a few global knowledge companies have exploited this market - Google (Scholar), Reed Elsevier (Scopus), and Thomson Reuters (which bought the Institute for Scientific Information, ISI, in 1992). The latter is a company which has invested in a strategy of horizontal integration, which means that they now own a series of products which are used to manufacture, display or analyse the knowledge produced by other knowledge companies. Thomson Reuters now owns "Reference Manager" and "EndNote", both products used by academics to produce papers for journals. They also own "ScholarOne", the market leading online journal editing software, which is leased to other companies so that they can produce their journals - as Manuscript Central which is used by Organization for example. The "Current Contents" alert markets the papers in journals to academics who will then in turn have their citations analysed through the ISI Web of Knowledge system, which includes the Social Science Citation Index. Finally, if they are successful at using all these Thomson Reuters products, they might find themselves in the ISI "Highly Cited" lists. The other products are interesting, because they are links in the chain which provide profits, but it is the ISI which concerns us most here.

In some sense, we could imagine the ISI lists as the end of the process, but they are actually the key feedback loop which then generates much of the dynamic which makes the other products profitable too. It is in solving and then monetising the ranking problem, the problem of who to trust most, that ranking entrepreneurs find a unique place within the system of academic journal production. Their analyses of citations in listed journals - originally a tool for scientists to trace ideas (Garfield 1955) - have now become crucial forms of information which orients the decisions of individual academics, their employers, and the other horizontally integrated firms we have already discussed. Aggregate numbers of citations for academics and for journals are now a commodity which will be paid for by individuals and institutions. The impact factor (IF) of a journal, which is a derivative of the collected citation data, can then be combined into a list of relative impacts, such as that within management which in 2012 ranked around 172 journals against each other. The IF is not the only way in which citations can be turned into a list, but it is a powerful one because of its quantification ${ }^{5}$. Other ranking entrepreneurs have used different criteria, such as the results of the British Research Assessment Exercise, and combined them with the IF to produce a scoring system for Management journals. Initially launched by the then rather moribund organization "The Association of Business Schools", the ABS list rapidly eclipsed the wide variety of lists that preceded it in the $\mathrm{UK}^{6}$ and gave the organization a central place in British, and increasing European, management education. Other lists, such as the Australian Council of Business Deans, and the Financial Times (owned by Pearson PLC) also bring power, publicity and/or income to their respective originators. The production of the list itself appears to stabilise a certain sort of relation between universities, academics and capitalist firms which trade in knowledge.

This is also true of the various other attempts at quantifying the work of academics, such as the attempts to measure productivity over time, the overall number of citations as well as their distribution. So a measure like the $\mathrm{h}$-index ${ }^{7}$ uses ISI citation data too, though it can also use the data provided by Google Scholar by using a tool such as Anne-Wil Harzing's web based "Publish or Perish" (www.harzing.com). The h-index summarises the academic as a number, and such a number can then be benchmarked against the average for any particular academic discipline. My point is that these technologies provide a mechanism which links some words published in a journal to citations or other metrics. In doing so, they neatly solve a series of problems for academics who want promotion and pay rises, their employers who

\footnotetext{
${ }^{5}$ This is not to say, of course, that it is a robust measure of the quality of work within a given journal either. For a critique of this assumption, see Starbuck 2005.

${ }^{6}$ Such as the Bristol Business School list, the Aston list, etc. As of 2014, the ABS list will be published as the International Guide to Academic Journal Quality.

${ }^{7}$ A measure of citation and productivity in which an academic's index is $\mathrm{h}$ if they have $\mathrm{h}$ publications cited $\mathrm{h}$ times.
} 
want to discipline labour and sell education, state bodies which have the problem of allocating research funding, and capitalist firms which want to make profits.

As an editor, academic authors contact you continually. They email queries about possible papers and special issues, ask to meet at conferences, send polite and apologetic nags about delays in decisions, thanks for revise and resubmits and effusive thanks for acceptances. Sometimes they remind you that they need a decision because they are preparing a CV for a job application or promotion. There are even thanks for rejections, which suggests a degree of attempted future proofing on the assumption that an editor will note your humility and bear it in mind for next time. Most of the communication I received was careful, deferential. It noted that I was very busy, and that I might not have time, and that there was no hurry. They seemed to be constructing me as someone who mattered, who should not be offended, and whose good graces needed to be relied upon. The idea of the editor as powerful decision maker seemed to be embedded into their modes of address.

Not always of course, because some (but remarkably few) rejections resulted in snarling sarcasm about the intelligence or integrity of the editorial processes, or long emails which contrasted what reviewer one and four said with what was written in the article, and suggested that a particular point was wrong or misunderstood, and that reviewer three really liked the paper and wanted to see it published. Early in my tenure I did reply to them and tried to justify the decisions made. The fact that this always produced further emails was enough to make me realise that silence, or a regretful but firm reiteration of the decision, was the best strategy.

For all these authors, my "decisions" mattered, and whether placating a kindly god or railing against a cruel one, their emails clearly reflected the urgent need to publish. These were PhD students who needed a publication to get a job, young academics who needed to get off probation or wanted to get promotion, older academics who needed validation. For many, there was a need to get journal articles in order to be entered for research assessment exercises, annual reviews, or as lines on a CV to get them a better job or more money. They seemed to believe that a smile from my throne would make a difference.

\section{Decision Pending}

When I began the work of editing, the actual process of making decisions about what to publish and what to reject appeared at first to be embedded in the detail of what I was doing. Most of my work happened on a piece of software owned by Thomson Reuters and sold with the line "Don't just manage a process. Advance your business", and on a laptop which I had bought with royalties from SAGE. An Associate Editor and a few reviewers (employed by some other universities) gave me their opinions about a submitted paper, and it was up to me to make the call. The software prompted me to make decisions, and so I did. Yet after a few years, and hundreds of papers, I began to feel that my job was actually to provide the impression that I was making decisions, and that I was usually just a relay for much more subtle and complex forces which had already shaped the decision for me ${ }^{8}$.

For example, since I selected the Associate Editors from people I knew or who were recommended to me by people I knew, they in turn often selected reviewers from a similar pool of like-minded academics from a series of familiar universities in certain countries. This isn't to say that the people then making decisions on a paper were homogeneous, but they were certainly drawn from a predictable pool of institutions, conferences, PhD students and supervisors and the authors and boards of related journals. For example, the papers that tended to be accepted came from institutions which had a well developed set of processes for ensuring that their academics are published in highly ranked journals, including junior academics coauthoring with senior figures in the field. A fair number of these people were reviewers for the journal. The papers that were rejected often came from locations where there were relatively underdeveloped systems for ensuring that submissions were attuned to the language and concerns of the journal. This meant that the papers more likely to fit were those that reflected

\footnotetext{
${ }^{8}$ I am not here discussing other social psychological problems with the idea of peer review, such as confirmatory bias and so on (see Hojat 2003).
} 
the currently fashionable concerns of academics in highly ranked institutions in the Global North (Murphy and Zhu 2012). They were also papers which were around 8000 words long, written in fluent academic English and in a recognisable academic style, with references to papers in journals which academic libraries would have to pay for.

For example, with around 300 submissions to the journal per year, and around a day a week to spend on them, I could not read all the papers and reviews properly and was almost certainly unduly influenced by names and institutions I knew, Associate Editors and reviewers I trusted". The "invisible college" which Jones et al criticised in 2006 describes a set of social relations based on trust and proximity, and which hence tends to reproduce what it knows. For example, the authors who had locations which provided institutional support to go to conferences which I was likely to attend (including some very expensive ones) were more likely to be able to speak to me in person about the possibilities for getting published in the journal, or attend workshops in which editors talked about how you get published in journals like theirs. For example, since the Associate Editors and reviewers are not paid, I had to ensure that they felt valued for their labour, so it was difficult to disagree with their suggestions at risk of antagonising people I needed to keep onside. Agreeing was by far the easiest option, because if I discounted what they said (even I did disagree with it) they might withdraw their labour. If I did disagree with a reviewer or Associate Editor's letter, I would feel that I had to do a fair amount of repair work in order to ensure that offence was not taken.

For example, the journal's publisher at SAGE was always insistent that we needed to pay attention to the IF, and (despite my avowed position not to care about matters) she gently and insistently reminded me that it did matter to authors. Quite a few of the Associate Editors agreed with her, quite correctly. If the IF was too low, and the ranking in the management list too low, then many authors (particularly North American ones) would be discouraged by their institutions from submitting to the journal at all, even if they were sympathetic to its critical politics. Since these would be authors from institutions which had the infrastructure to support successful submissions then this would mean that most of our submissions would be from second tier institutions, producing work which was less cited by academics in first tier institutions and so on, which would further damage the IF and so on. This meant that SAGE, myself, and the editorial board often discussed the "gaming" strategies used by some journals, such as encouraging citation of the journal in editorial response letters, publishing citeable work early in the year, and so on. We decried such strategies, but did commission some review articles and considered the topicality of special issues (both of which are usually highly cited). We also agreed that we wouldn't do anything which would damage the IF for the sake of it. We never discussed the fact that a low IF would also damage SAGE's profits, our royalties, affect the investment the journal would receive and so on.

At conferences where I mattered, other things shifted. I became conscious that people I had never met started to be nicer to me than I deserved, laughing slightly too hard and being a little too attentive (cf. Parker 2004). I began to be more careful about what I said to people I didn't know well. People would approach me and ask me for advice about a paper and its suitability for the journal. They would listen to my platitudes with care, thank me fulsomely and then leave me to the others who were waiting to talk to me. Others seemed to have a coolness about them, and after a while, might remind me that I must remember that Organization had rejected one of their papers last year. Since we rejected 250 papers a year at that point, I would not remember, and simply apologise with a smile that I hope they understood as rueful. In one case, I met someone in the afternoon who I had written a rejection email to that morning. On a quite a few occasions, I was in the audience when papers which had been rejected were being presented, and the reasons for the (stupid, reactionary, defensive) rejection would become part of the justification for the paper. On many occasions, people made inferences or claims about acceptances or rejections which I didn't agree with, but again I would deploy the smile. I started to feel slightly paranoid, assuming that the niceness was forced, but the complaints were continual. When talking about the journal, I began to feel defensive, and feel that I needed to respond to complaints about journals and publishers,

\footnotetext{
${ }^{9}$ Here again, I need to be clear that this was my experience. It may not have been that of my co-editor.
} 
because they were really attacks on Organization, on my working for SAGE, on the integrity of my decisions.

\section{Follow the Money}

In order to understand why universities are content to have their employees partly working for publishers we need to think about the reputational and financial gains that might come from publishing and editing journals. This will either be via the state funding that is allocated following an audit of publications, as is the case in many countries, or simply because of the marketing claims that can be made about the implied quality of the services provided because of the "quality" of research output. However, this is rarely considered to be a hidden subsidy for publishers or commercial ranking entrepreneurs. Instead it is articulated more simply as a form of measurement of reputation which uses particular forms of evidence based quantification.

Such measures then become important in a series of ways for the internal management of the organization too. They allow employers to make decisions about recruitment, probation and promotion by attaching particular numbers to different individuals based on their success at publishing (Harvie 2000, De Angelis and Harvie 2009). In British Business Schools at the present time, the use of the ABS list has led to the fetishization of the notional $4 \times 4^{*}$ academic, someone who could be expressed as a number between 0 and 16 (Parker 2014b). More generally, the use of the ISI Highly Cited tool is beginning to be used at institutional level to measure the number of academic superstars who are employed by any given university. On an aggregate level, measures like this also allow employers to make decisions about resource allocation based on disciplinary units which are more or less successful in producing output. Departments have been closed and others have expanded because of their relative successes and failures in this regard. Finally, they also allow state funding bodies and research councils to make decisions concerning which employees and universities should have further resources allocated to them.

In a thoroughly predictable recursion, many of these measures are also feeding into league tables which (in part) rate universities based on their success in hiring and retaining academic staff who publish in highly ranked journals. The collective position in this list then provides the entire university with a number, which in turn feeds through to marketing and pricing strategies which ensure that enough money is being made from selling courses in order to pay the academics who are successfully publishing in highly ranked journals as well as those who manage them. This might be through higher salaries in research universities, or employer payments for publication in particular outlets, promotions for those who succeed and teaching intensive contracts for those who fail. In other words, my actions as editor of a mid range journal become one small element of the labour management and marketing strategies for academics like me. The "decisions" I make, and that are made about my work, feed directly into a collective audit of individual success or failure which results in financial rewards and penalties. Which includes this article, in this journal.

Each decision, each press of a button, might not seem to matter very much, and the pressures that impinge upon them might seem slight, but the pattern they make emerges from repetition.

When I pressed the buttons on Manuscript Central, processing the work, the last fail safe before sending the decision email was 'Are you sure?' I sometimes paused to think that I was ruining someone's day, or helping them get a promotion, because whichever button I pressed it would be inscribed on their CV, as a presence or absence. I sometimes thought about the third of a million I was helping to make for SAGE and what would happen if I didn't work for them for one day a week.

When my replacement was agreed by the journal's board, I sent out an email, copying in the SAGE editor. By return I got an angry email from her reminding me that SAGE appointed the editors, not me, and I shouldn't send emails like that without asking her first. We made friends quickly enough, but the reminder was helpful. 


\section{Cui Bono}

"We live in a society where the formation, circulation and consumption of knowledge are something fundamental. [...] Furthermore, the exercise, production and accumulation of knowledge cannot be disassociated from the power mechanisms with which they maintain complex relationships that must be analysed. [...] Which leads one to thoroughly reexamine the postulate according to which the development of knowledge constitutes a guarantee of liberation" (Foucault 2000, 291).

Who benefits from this set up? I have described a field which will be familiar to the readers of this journal, and I have placed myself within it. A reflective actor perhaps, cynical, but still one performing the functions which were expected of me (Kunda 1992, Fleming and Spicer 2003). By spending five years working for SAGE I helped to produce expanding profits for global companies; influence for ranking entrepreneurs; measures which determined the state research funding for universities as well as improvements in league table positions which in turn lead to increases in applications and enrolments for universities; as well as pay and status for academics. That included me, because my salary increased because I was editing the journal. And it wasn't particularly unpleasant work either, and was rewarding in terms of airfares, hotel bills and free lunches with lemon foam. If you are an academic in a research university in the Global North, publishing in highly ranked journals; or the employee of a global knowledge company; or an university manager or state policy maker looking for metrics that can be used to ration expenditure and reward "excellence", the set-up works for you.

But these are not the only people who might care about what journal editors do. For a start, there are other policy makers, academics and hacktivists who are concerned about the ways in which the marketization of journals impacts on the library budgets of universities and the use of university labour, and consequently on the costs of university education for taxpayers and students. Since this monetization is predicated on subscription costs, pay walls and so on, librarians and finance officers are rarely positive about these developments, predicated as they are on above inflation increases in subscription costs to "must have" journals. This has been one of the reasons that there has been a recent and vigorous debate about the dissemination of the results of publically funded science, and which has resulted in a number of policy proposals in the global north which attempt to intervene in the process by which knowledge capitalists (though not ranking entrepreneurs) extract value from the pro$\operatorname{cess}^{10}$. From academics and citizens there have there been petitions against particular publishers (such as Elsevier ${ }^{11}$ ), sustained criticism of the practices of others (such as Emerald/MCB, see Davis 2005), journal editors refusing rankings and assessment ${ }^{12}$, editorial boards leaving publishers to set up their own journals and much discussion of open access and e-journals (Beverungen et al. 2012, Harvie et al. 2012, Harvie et al. 2013, Fuchs and Sandoval 2013). Whatever the merits of these proposals and activities, the diagnosis is clear. The publishers of journals are engaging in hyper-profitable activities which extract value from university and state budgets, and prevents the general public from reading their journals. The editors of these journals are helping them to do it, even if they can't see the strings.

There is a further consequence I think, and this relates to the way in which the expectations of academics in the research universities of the global north are being shaped by these processes. It is clear enough that highly ranked journals, and hence often the most profitable journals, are those in the centre of disciplines (Li and Parker 2013). That is to say, if an academic's choices about where to publish are shaped by IFs and related technologies, then they will tend to head for the established core problems. The activities of the ranking entrepreneurs who provide the information which regulates and legitimates the explosion of journal publication have a further (unintended) consequence - that they reward those who adopt

\footnotetext{
${ }^{10}$ Best developed at the moment is the UK "Finch Report", www.researchinfonet.org/publish/finch/, a method of extracting value from university library budgets at a different point in the process.

${ }^{11}$ See Ted Bergstrom's Journal Pricing Page, www.econ.ucsb.edu/ tedb/journals/jpricing.html.

12 For example, see www.ncbi.nlm.nih.gov/pmc//articles/PMC2629173/, and the San Francisco Declaration on Research Assessment, http://am.ascb.org/dora/.
} 
mimetic intellectual strategies. We might interpret this in a number of ways - methodologically, conceptually, politically and so on - but the fact remains that work which tends to be more heterodox, marginal, interdisciplinary or critical will tend to be more likely to be rejected (Lee 2007, Post 2012, Alvesson and Gabriel 2013). This is a logical consequence of any ranking system, simply because it is a machine designed to reduce diversity. This "middle" is also one that has clear consequences for audiences because of the ways in which it discourages certain forms of thought, and also because it assumes an audience working in institutions which have access to the products of the knowledge industries. Just as the ranking system tends to reduce diversity of product, so does it assume homogeneity of readership.

This drift towards the middle is an inevitable consequence of the dissemination and use of techniques which measure and compare, of the explosion in the number of academic journals because of their profitability, of the ways in which the combination of both are used by university managers and some state policy makers. Like US TV, the sheer expansion in the number of channels belies the fact that most of the content is the same, since it is driven by the same socio-economic forces. For many academics, they are aware that they shouldn't waste their time on books, chapters in books, blogging, journalism and so on. Neither should they write for low ranking journals, and this means that they are encouraged to write into the middle. A middle that benefits knowledge corporations, university managers and ranking entrepreneurs, and provides benefits in terms of pay and status for those academics who succeed, and enrolments and fees for those institutions that employ them. Like many parts of the culture industries, this is a middle which is produced by market forces, by assumptions about what sells and what audiences want. It encourages mimetic behaviour by producers, since their output and/or profitability is shaped by what ranking entrepreneurs tell them audiences want.

The problem that this leaves us with, for this issue of an open access journal, is that even if you take the global capitalists out of the process, the rest of the set up stays the same. That is to say that states, universities as competitors and employers, academics and (perhaps most importantly) ranking entrepreneurs will generally continue to operate in the way that I have described. For a wide variety of reasons, we should certainly ensure that people can read our work, particularly that work which has been funded by taxpayers and that global knowledge corporations make their money re-selling. Soft and hard boycotts of certain publishers (Pablo K 2013) and the building of open access architectures (green or diamond, Fuchs and Sandoval 2013) are clearly a good thing in this context. There is also convincing evidence that open access will be good for innovation and university library budgets (Houghton and Oppenheim 2010).

However, this doesn't solve all the problems with knowledge production and its location in the academic journals of the Global North. In a world of "big data", the ranking entrepreneurs will be able to measure citations and clicks, $h$ and i10 indexes, and hence continue selling these measures to states and universities willing to pay for them. These will be measures of central tendency, of the volume and importance of certain forms of knowledge production and dissemination that reflect the centripetal social processes that tend to produce more of the same in style and content, and reward academics with pay rises and promotions when they produce formulaic research (Alvesson and Gabriel 2013). Open access journal publishing is important, but it's just the first step on a much bigger project, that of imagining the open access university. This means encouraging forms of academic writing which are comprehensible to non-academic readers, and hence can be read widely even if there is no paywall. Once the journal publishers are out of the picture, the ranking entrepreneurs are the next major obstacle to the realization of such a goal.

I'm not the Editor-in-Chief any more, and I'm pleased about that. I think I did the job OK, but I don't feel very proud of what I have done. Others might have different accounts, but I feel as if I spent five years playing at being a judge, deciding who should win and who should lose, when all the while the competition was fixed. I knew that it was fixed, but kept on doing what I did nonetheless. Not "pretending" in the sense that an active hypocrite might, but ignoring, bracketing, not seeing. And I would use various phrases to reassure and distract myself, such as the idea that Organization was "community property" which I was a steward of 
for a while, or that I didn't want to be "a bureaucrat of knowledge", simply applying the rules established by adding up the preferences of reviewers and editors. I even wrote and cowrote editorials in which I/we insisted that this journal was different, and that we didn't care about playing citation games (for example, Parker and Thomas 2011). And all the while, Organization was finding its way onto CVs, into promotion applications, into IF databases, ranking lists and the management accounts used by SAGE. Just as this paper will, in this journal. Once you are so firmly embedded in the game, the game plays you. The Editor is edited, because working within the system that forms, circulates and consumes knowledge is no guarantee of liberation. Unless I stop doing this now, in this way, and try to work towards a different way of thinking about the "formation, consumption and circulation of knowledge". In Peter Berger's words:

"Unlike the puppets, we have the possibility of stopping in our movements, looking up and perceiving the machinery by which we have been moved. In this act lies the first step towards freedom" (1966: 199).

\section{References}

Alvesson, Mats and Yiannis Gabriel. 2013. Beyond Formulaic Research: In Praise of Greater Diversity in Organizational Research and Publications. Academy of Management Learning and Education 12 (2): 245-263.

Berger, Peter.1966. Invitation to Sociology. Harmondsworth: Pelican.

Beverungen, Armin, Steffen Böhm and Chris Land. 2012. The Poverty of Journal Publishing. Organization 19 (6): 929-938.

Davis, Philip. 2005. Article Duplication in Emerald/MCB Journals is more Extensive than First Reported. Library Resources and Technical Services 49 (3): 148-150.

De Angelis, Massimo and David Harvie. 2009. "Cognitive Capitalism" and the Rat-Race: How Capital Measures Immaterial Labour in British Universities. Historical Materialism 17 (3): 3-30.

Editors. 2012. Notes from the Editors. Monthly Review 64 (5), October.

Fleming, Peter and André Spicer. 2003. Working at a Cynical Distance. Organization 10 (1): 157-179.

Garfield, Eugene. 1955. Citation Indexes for Science: A New Dimension in Documentation through Association of Ideas. Science 122: 108-111, July.

Foucault, Michel. 2000. Interview with Michel Foucault. In Power: The Essential Works of Foucault 1954-1984, ed. James D. Faubion, 239-297. Penguin: London, 239-97.

Fuchs, Christian and Marisol Sandoval. 2013. The Diamond Model of Open Access Publishing. tripleC - Communication, Capitalism and Critique 11 (2): 428-443.

Harvie, David. 2000. Alienation, Class and Enclosure in UK Universities. Capital and Class 71: 103132.

Harvie, David, Geoff Lightfoot, Simon Lilley and Ken Weir. 2012. What are we to do with Feral Publishers? Organization 19(6): 905-914.

Harvie, David, Geoff Lightfoot, Simon Lilley and Ken Weir. 2013. Publisher, be damned! From Price Gouging to the Open Road. Prometheus 31 (3).

Hodges, Wilfrid. 1998. An Editor Recalls Some Hopeless Papers. Bulletin of Symbolic Logic 4 (1): 116.

Hojat, Mohammadreza, Joseph Gonnella and Addeane Caelleigh. 2003. Impartial Judgment by the "Gatekeepers" of Science: Fallibility and Accountability in the Peer Review Process. Advances in Health Sciences Education 8 (1): 75-96.

Houghton, John and Charles Oppenheim. 2010. The Economic Implications of Alternative Publishing Models. Prometheus 28 (1): 41-54.

Jones, Oswald, Sudi Sharifi and Steve Conway. 2006. Accounting for Organization: Round up the Usual Suspects. Accounting, Organizations and Society 17 (2-3): 283-304.

Kunda, Gideon. 1992. Engineering Culture. Philadelphia: Temple University Press.

Lee, Fred. 2007. The Research Assessment Exercise, the State and the Dominance of Mainstream Economics in British Universities. Cambridge Journal of Economics 31 (2): 309-325.

Li, Eldon and Martin Parker. 2013. Citation patterns in Organization and Management journals: Margins and Centres. Organization 20 (2): 299-322.

McCune, Sarah Miller. 2010. Being SAGE. Memories of the First 45 Years. Thousand Oaks, CA: SAGE. 
Pablo, K. 2013. On Rejecting Journals. The Disorder of Things http://thedisorderofthings.com/2013/07/25/on-rejecting-journals/. Accessed August 14, 2013.

Parker, Martin. 2004. Becoming Manager. Management Learning 35 (1): 45-59.

Parker, Martin. 2014a. Writing: What can be said, by who, and where? In Critical Management Research: Reflections from the Field, ed. Emma Jeanes and Tony Huzzard. London: Sage.

Parker, Martin. 2014b. University Ltd. Organization 21 (2).

Parker, Martin and Robyn Thomas. 2011. What is a Critical Journal? Organization 18(4): 419-427.

Pirie, Ian. 2009. The Political Economy of Academic Publishing. Historical Materialism 17 (3): 31-60.

Post, David. 2012. Rank Scholarship. Comparative Education Review 56 (1): 1-17.

Shapin, Steven. 1994. A Social History of Truth: Civility and Science in Seventeenth-Century England. Chicago, IL: University of Chicago Press.

Sparkes, Andrew. 2007. Embodiment, Academics and the Audit Culture: A Story Seeking Consideration. Qualitative Research 7 (4): 521-550.

Starbuck, William. 2005. How Much Better are the Most Prestigious Journals? The Statistics of Academic Publication. Organization Science 16 (2): 180-200.

Williams, Jeffrey. 2010. My Life as an Autocratic Editor. The Chronicle of Higher Education, June $13^{\text {th }}$.

\section{About the Author}

Martin Parker works at the University of Leicester School of Management. His recent writing includes Alternative Business: Outlaws, Crime and Culture (Routledge 2012), and the co-edited Companion to Alternative Organization (Routledge 2014). A list of his publications can be found at https://sites.google.com/site/martinparker1962/ or

http://www2.le.ac.uk/departments/management/people/mparker 